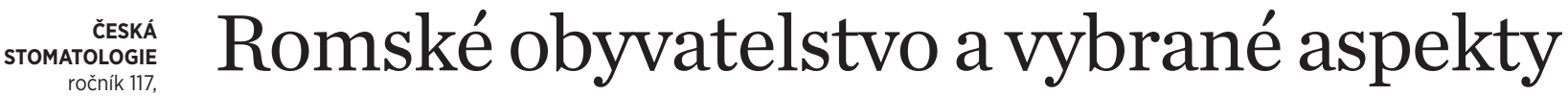 stomatologické péče
}

(Původní práce - epidemiologická kohortová studie)

\section{The Roma Population and Selected Aspects of Dental Care}

(Original Article - Epidemiologic Study)

Karásková P., Kajanová A.

Ústav sociálních a sociálně pedagogických věd ZSF JU, České Budějovice

\section{SOUHRN}

Cíl: Článek se věnuje tématu stomatologické péče u romských pacientů. Reflektuje absenci dat v této oblasti. Literatura poukazuje na celkově zhoršený zdravotní stav romské minority, který je ovlivněn primárně nevyhovujícím sociálním prostředím, ale rovněž některými kulturními charakteristikami.

Metodika: Článek prezentuje data z výzkumu realizovaného dotazníkovým šetřením u zubních lékařu v Českých Budějovicích, kteři mají ve své evidenci Romy $(n=37)$, a dále pak u romských obyvatel ve věku vyšším než patnáct let tamtéž $(n=237)$. Data byla statisticky zpracována v programu SPSS.

Výsledky ukázaly na nízkou míru registrace romských pacientů a rovněž malý zájem se registrovat. Častěji se registrují zaměstnaní a ženy. Registrovaní pacienti mají větší povědomí o rizicích spojených s nedostatečnou péčí o chrup a méně často vyhledávají služeb zubní pohotovosti. Disponují rovněž informacemi o tom, na jaké ošetření mají nárok. Neregistrovaní Romové vyhledávají informace v rámci rodiny a médií. Zubní lékaři poukázali na malou četnost preventivních návštěv u romských pacientů, kteří nejčastěji zubního lékaře navštěvují až v případě akutní bolesti, a obecně na nízký zájem o péči o chrup u této cílové skupiny.

Závěr: Výzkum poukázal rovněž na některá možná nedorozumění - např́klad obavy romských pacientů z toho, že je lékař nebude chtít registrovat. Řešením může být spolupráce se sociálním nebo zdravotně sociálním pracovníkem, který by představoval komunikační můstek mezi lékařem a romským pacientem a mohl by rovněž realizovat preventivní aktivity př́mo v terénu.

Klíčová slova: zubní péče - romská minorita - preventivní péče - informovanost

\section{SUMMARY}

Aim of study: The article discusses the topic of dental care for Roma patients. It reflects the absence of data in this area. Literature points out the generally deteriorated health condition of the Roma minority, primarily affected by unsuitable social environment, but also by some cultural characteristics.

Material and methods: The article presents the data from the research implemented by questionnaire investigation made among dentists in České Budějovice who have Roma patients $(n=37)$ in their records, as well as among Roma inhabitants over 15 years in the same town $(n=237)$. The data were statistically processed in SPSS Program.

The results showed low lever of registration of Roma patients, as well as low interest in registering. Employed persons and women register themselves more often. The registered patients usually are more aware of the risks related to insufficient care for their teeth and seek less often the dental emergency services. They also have information about the treatment they are entitled to. Unregistered Roma seek information within their family and in the media. The dentists pointed out low level of preventive visits of Roma patients, who usually go to the dentist only when they have acute pain, and the generally low interest in care for teeth in this target group.

Conclusion: The study also showed some potential misunderstandings - for example the Roma patients' fear that the dentist won't want to register them. A solution may consist in cooperation with a social or 
health and social worker who would constitute a communication bridge among the dentist and the Roma patient and who also could implement preventive activities in field.

Keywords: dental care - Roma minority - preventive activities - information on available care
Čes. Stomat., roč. 117, 2017, č. 1, s. 8-12

\section{ÚVOD}

Ačkoli se vládní politika snaží eliminovat rozdíly ve zdraví české populace, výzkumy potvrzují přetrvávající diferenci v ukazatelích zdravotního stavu mezi jednotlivými sociálními vrstvami, ale také mezi majoritou a minoritními skupinami. $\mathrm{Z}$ výzkumu SASTIPEN „Zdravía romská komunita, analýza situace v Evropě" vyplynuly velmi důležité faktory, ovlivňující zdravotní stav romské populace, která představuje naši nejpočetnější etnickou minoritu [2]. Jedná se o:

- odlišné pojetí vztahu k vlastnímu zdraví, včetně přístupu k prevenci,

- odlišný způsob stravování, hygienických a vyživovacích zvyklostí,

- zdravotně rizikové prostředí sociálně exkludovaných lokalit, v němž velká část romského obyvatelstva žije [9].

Z různých výzkumů zaměřujících se na zdravotní stav romské minority je patrné, že specifickým problémem ze strany zdravotnických pracovníků je diskriminace [5]. Mnoho zdrojů uvádí neochotu lékařũ, a především pak specialistů registrovat romské pacienty (srov. např. [4]). Na druhou stranu je třeba upozornit na to, že odmítnutí Roma lékařem však nemusí být $z$ důvodu diskriminace. Zákon 372/2011 Sb., o zdravotních službách a podmínkách jejich poskytování, zná situace, kdy je lékař oprávněn kteréhokoli pacienta odmítnout registrovat, popřípadě ukončit péči o něj. Jedná se o případ, kdy by přijetím pacienta bylo překročeno únosné pracovní zatížení, nebo jeho přijetí brání provozní důvody, personální zabezpečení nebo technické a věcné vybavení zdravotnického zařízení. Důvodem může být též opakovaná absence domluvené návštěvy k ošetření.

Ačkoli výzkumný zájem o romskou minoritu v souvislosti se zdravotním stavem spíše roste, výzkumy zaměřené na stomatologická témata a romskou minoritu jsou naprosto ojedinělé. Celoplošně je výjimkou evropský projekt „Zdraví a romská populace“ z roku 2009, kdy byla vypracována analýza, kterou koordinovala španělská nadace Fundación Secretariado Citano. Týkala se sociální a zdravotní situace romské populace a byla realizována v sedmi evropských zemích včetně ČR [7]. Pro potřeby našeho článku uvádíme výsledky v oblasti stomatologické péče. Pokud jde o návštěvnost romské populace u zubních lékařơu, nasvědčuje mnohé tomu, že důvodem návštěvy bývá spíše akutní problém než preventivní prohlídka. Šedesát osm procent respondentů navštívilo stomatologa před rokem a více, dvacet tř̌i procent v rozmezí tří až jedenácti měsíců, a devět procent respondentů dokonce zubní vyšetření či ošetření nikdy neabsolvovalo. $\mathrm{Z}$ respondentů, kteří během posledních tři měsíců zubního lékaře navštívili, musela jich zhruba polovina návštěvu i několikrát opakovat. To naznačuje, že se nejednalo o cílenou preventivní prohlídku, ale že přišli již $\mathrm{s}$ problémem, který bylo nutno vyřešit $\mathrm{v}$ několika návštěvách. Velmi zajímavé je, že dosti podobné výsledky vycházejí u všech zkoumaných věkových skupin. Pouze o něco výraznější odchylky jsou u frekvence návštěv mužů a žen, kdy se zjistilo, že ženy chodí pravidelněji. Pokud jde o typ zdravotnického zařízení, preferují Romové ve velké většině státní zdravotní systém (smluvní lékaře se zdravotními pojištovnami) [7].

Stav chrupu romské populace je zde hodnocen podle počtu terapeutických výkonů, jakými jsou výplně a dostavba kariézních zubů, extrahované zuby, parodontologické obtíže a př́tomnost protetických prací. V nejlepším stavu má zuby nejmladší zkoumaná generace ve věku 16-21 let, i když ne zcela jednoznačně. Každý pátý $z$ nich nemá kompletní chrup a má i více než čtyři ze zkoumaných terapeutických úkonů. Zajímavá je i existence vlivu prostředí na stav chrupu. Nejméně potíží mají Romové v malých městech a na vesnicích, naopak ve velkých městech mají potíže největší. To se týká i celkového zdravotního stavu [7]. Romové často nemají zájem o protetickou náhradu chybějících zubů, což je možné přičíst jejich socioekonomické situaci. Některé typy náhrad sice hradí zdravotní pojištovna plně, ale kvůli malé informovanosti v této oblasti může pojem náhrada vyvolat mylnou představu vysokých výdajů. Přístup Romů k péči o zuby je velice nedbalý $\mathrm{v}$ tom, že dokud nenastane vážný problém, který je nutno řešit $z$ důvodu bolesti (estetika není na prvním místě), nepřipadá převážné většině respondentů nutné navštívit zubního lékaře [7]. Podobná situace je popisována i v obecném př́i- 
ČESKÁ STOMATOLOGIE ročník 117 2017 s. 8-12 stupu ke zdraví, kdy preventivním aktivitám není věnována př́liišná pozornost [3].

Náš článek navazuje na chybějící data o informovanosti romské minority $\mathrm{v}$ oblasti stomatologické péče. Klade si za cíl jednak zjistit informovanost a ochotu romského obyvatelstva k preventivním zubním prohlídkám a dále pak zjistit ochotu zubních lékařů Romy ve svých ordinacích registrovat. Stanovily jsme si rovněž dvě výzkumné otázky:

1. Mají romští obyvatelé dostatek informací o následcích zanedbání zubní péče?

2. Jaké jsou příčiny neochoty registrace romských občanů u zubních lékařů?

\section{METODY}

Pro realizaci výzkumného šetření byla zvolena kvantitativní výzkumná strategie, technika dotazníkového šetření s otázkami uzavřeného, polootevřeného i otevřeného typu. Výzkumný soubor představovali jednak zubní lékaři v Českých Budějovicích, kteří mají ve své evidenci Romy, a dále pak romští obyvatelé ve vyšším věku než patnáct let tamtéž. Dotazník určený pro zubní lékaře se $v$ celkem jedenácti otázkách zaměřoval na ochotu registrovat nové romské pacienty, ale i na zkušenosti s romskými pacienty již registrovanými. Byli osloveni všichni zubní lékaři v regionu, tj. 130 osob. Souhlas s vyplněním dotazníku byl získán celkem od 89 z nich, $\mathrm{z}$ nichž ale pouze 37 mělo ve svém registru romské pacienty. Devatenáct lékařů uvedlo, že počet romských pacientů nepřekračuje jedno procento všech registrovaných pacientů, naopak u osmnácti ošetřujících bylo procento vyšší.

Dotazník určený romské minoritě byl vyplňován spolu s respondenty podobou řízeného rozhovoru a obsahoval sedmnáct otázek, které se týkaly zejména péče o chrup, návštěv zubního lékaře a informovanosti o možných rizicích při nedodržování preventivních opatření. Dotazníky byly získány od 237 osob vybraných náhodným výběrem. Faktor etnicity byl ošetřen úvodní otázkou: Považujete se za Roma/Romku?

Dotazníkové šetření bylo statisticky zpracováno v programu SPSS pomocí $\chi^{2}$ testu.

\section{VÝSLEDKY}

Výsledky našeho výzkumu potvrdily proklamovanou nízkou četnost registrací romského obyvatelstva u zubních lékařů. V našem souboru bylo pouhých $35 \%$ Romů aktuálně registrovaných. Statisticky významně častěji $\left(\mathrm{p}=0,04, \chi^{2}\right.$ test $=$ $16,92)$ byly u zubního lékaře registrovány ženy než muži, žen nebylo registrováno celkem 50 \%, mužũ 76 \%. Z neregistrovaných dvou třetin respondentů má potřebu registrace pouhých $33 \%$ respondentů, a to $z$ většiny $(20 \%)$ proto, že mají akutní potíže. Zbývajících 67 \% respondentů uvedlo, že k zubnímu lékaři chodit nechce. Důvodem je strach (23\%), nezájem (24\%) nebo absence obtíží (20 \%) či obava z neochoty lékaře Roma registrovat ( $33 \%)$. Registrovanost statisticky významně souvisí se socioekonomickou situací respondentů. Nejvíce registrovaných dotazovaných bylo $v$ zaměstnaneckém poměru. Neregistrovaní naopak nejčastěji uváděli jiný zdroj př́ijmu - sociální dávka, rodičovská dovolená ap. $\left(\mathrm{p}=0,04, \chi^{2}\right.$ test $\left.=18,0\right)$.

Registrace pacienta má přitom prokazatelný vliv na stav chrupu v mnoha ohledech. Výsledky výzkumu ukázaly statisticky významnou souvislost registrace a návštěvnost lékařské služby první pomoci. Romové, kteří nemají svého zubního lékaře, navštěvují zubní pohotovost mnohem častěji než ti, kteř́i jej mají ( $\mathrm{p}=0,02, \chi^{2}$ test $\left.=19,4\right)$. O rizicích zanedbání zubní péče mělo dobrý přehled 65 \% registrovaných romských pacientů, zatímco neregistrovaní měli přehled pouze ve $35 \%$ a tvořili 74 \% všech, kteří o rizicích nevědí nic. Registrovaní pacienti získávají adekvátní informace od svého registrujícího zubního lékaře, zatímco neregistrovaní jsou bez informací nebo vyhledají nějaký alternativní zdroj, jako rodinu či média, případně mají vlastní zkušenost (tab. 1). Informovanost registrovaných a neregistrovaných romských respondentů vykazuje disproporce $s$ vyšším skóre úspěšnosti u registrovaných, kdy např. informace o úhradě výkonů zdravotní pojištovnou má $z$ registrovaných romských respondentů celých 70 \% a z neregistrovaných jen $30 \%$ respondentů.

U romských pacientů poukazovali zubní lékaři na nízkou četnost pravidelných preventivních pro-

Tab. 1 Zdroje informací o stomatologické péči u romských pacientů

\begin{tabular}{|l|l|l|l|l|l|}
\hline Zdroj informací & lékař & rodina & zkušenost & média & nikdo \\
\hline Registrovaní & 27 & 19 & 14 & 13 & 11 \\
\hline Neregistrovaní & 8 & 50 & 34 & 29 & 32 \\
\hline Celkem & 35 & 69 & 48 & 42 & 43 \\
\hline
\end{tabular}

Zdroj: vlastní výzkum 
Tab. 2 Vztah věku pacienta $\mathrm{k}$ vážnosti stomatologických obtiží, subjektivně

\begin{tabular}{|l|l|l|l|l|}
\hline & $\mathbf{1 5 - 2 4}$ let & $\mathbf{2 5 - 4 0}$ let & $\mathbf{4 1}$ a více & celkem \\
\hline Žádné obtiže & 49 & 13 & 5 & 67 \\
\hline Zanedbatelné nebo mírné obtiže & 13 & 8 & 18 & 39 \\
\hline Středně vážné až vážné obtiže & 19 & 48 & 9 & 76 \\
\hline Velmi vážné & 8 & 26 & 21 & 55 \\
\hline Celkem & 89 & 95 & 53 & 237 \\
\hline
\end{tabular}

hlídek. Celkem 57 \% dotázaných stomatologư uvedlo, že Romové preventivně do ordinací docházejí, 43 \% naopak uvedlo, že Romové stomatologa navštěvují pouze v případě bolesti. Většina dotázaných zubních lékařù (54 \%) hodnotí péči u romských pacientů jako nedostatečnou, 14 \% naopak jako výbornou a $32 \%$ jako průměrnou. Nebyla prokázána statisticky významná souvislost mezi počtem registrovaných romských pacientů a ochotou přijímat další; rovněž ani mezi ochotou registrovat a spokojeností se spoluprací s dosavadními romskými pacienty. Byl prokázán statisticky významný vliv věku pacienta na vážnost jeho obtíží se zuby ( $\mathrm{p}=0,000, \chi^{2}$ test $=$ $81,83)$. Pacienti ve věku 15 až 24 let nejčastěji uváděli, že obtíže se zuby nemají. Nejvíce obtíží uvádějí pacienti ve věku 25 až 40 let. Je zajímavé, že nejstarší část dotazovaných (41 a více let) uváděla menší obtíže než zmíněná kategorie 25 až 40 let. Zřejmě je to tím, že postupně zuby ztrácejí, a proto s nimi mají méně potíží (tab. 2).

\section{DISKUSE A ZÁVĔR}

Výsledky našeho výzkumu potvrdily data, která jsou dostupná ze zdravotních šetření týkajících se romské minority (např. [10]), tedy že ačkoli romská minorita vykazuje ve srovnání s majoritou horší zdravotní stav, je pouze minimálně registrována u lékařů. Současně je pak problémem nedostatečná prevence. Bezesporné ovšem je nadceňování vlivu etnicity a podceňování vlivu sociálních faktorů. Jinými slovy, primární přičinou zhoršeného zdraví a přístupu k němu nemusí být to, že se jedná o Roma či Romku, ale že se jedná o chudé, sociálně slabé osoby [5]. Především v podmínkách sociální exkluze dochází ke generačnímu předávání majoritně nefunkčních vzorců chování a jednání [11]. Problémy s chrupem začínají u sociálně slabých romských dětí již v dětství, kdy rodina mnohdy nedisponuje základním vybavením, jako je pasta a zubní kartáček, a děti nejsou k péči o chrup vedeny (vlastní poznatky). Jako možné řešení se jeví využít péče nízkoprahových zařízení pro děti a mládež (NZDM), ve větším měřítku služeb zubních hygieniček, které mohou dětem pomoci osvojit si vhodné hygienické návyky a díky „domácím úkolům" zprostředkovat tyto informace i ostatním členům rodiny. Dalším z možných řešení problémů zubní péče u Romů je účinná komunikace mezi romským pacientem a zubním lékařem. Dá se např. realizovat multikulturním vzděláváním zdravotnických pracovníků a spoluprací se sociálním pracovníkem jako mediátorem mezi nimi. Zavedení pozice zdravotně-sociálního pomocníka v rámci terénních programů se věnuje i „Strategie romské integrace do roku 2020“, kterou vypracovala Vláda ČR [2]. Tato strategie také zdůrazňuje vzdělávání lékařů a ostatních zdravotnických pracovníků pro práci s etnickou menšinou jako s osobami s typickými odlišnostmi. Neřešitelným problémem je ovšem obecný nedostatek zubních lékařů [8].

\section{LITERATURA}

1. Česko. Zákon č. $372 / 2011$ Sb., o zdravotních službách a podmínkách jejich poskytování (zákon o zdravotních službách).

2. Davidová, E., Lhotka, P., Vojtová, P. Právní postavení Romů $\checkmark$ zemích Evropské unie. Praha, Triton, 2005. ISBN 80-7254727-5.

3. Davidová, E., Matulay, S., Uherek, Z. Analýzy vybraných zkoumaných lokalit - základní údaje. In Davidová, E., a kol.: Kvalita života a sociální determinanty zdraví u Romů v České a Slovenské republice. Praha, Triton, 2010, s. 203-205. ISBN 978-80-7387-428-5.

4. GAC. Analýza sociálně vyloučených lokalit a absorpční kapacity subjektů působících $\mathrm{v}$ této oblasti [online]. Praha: Gabal Analysis and Consulting, 2006 [cit. 201605-24]. Dostupné z: http://www.gac.cz/userfiles/File/ nase_prace_vystupy/GAC_MAPA_analyza_SVL_aAK_ CJ.pdf?langSEO $=$ documents\&parentSEO=nase_prace_vystupy\&midSEO=GAC_MAPA_analyza_SVL_aAK_CJ.pdf

5. Gunarataman, J. Researching race and ethnicity. methods, knowledge and power. London, SAGE Publications, 2003. 217 s. ISBN 0-7619-7286-2.

6. Karásková, P. Informovanost romského obyvatelstva $v$ oblasti stomatologické péče. České Budějovice: Jihočeská univerzita. Zdravotně sociální fakulta. Ústav sociálních a sociálně pedagogických věd, 2016. 84 s., 5 s. príloh. Vedoucí diplomové práce doc. PhDr. Bc. Alena Kajanová, Ph.D. 
ČESKÁ STOMATOLOGIE ročník 117, 2017, 1, s. $8-12$

7. Nesvadbová, L., Šandera, J., Haberlová, V. Romská populace a zdraví: Česká republika - Národní zpráva 2009. Madrid: FSG, 2009. ISBN 978-84-692-5535-3.

8. Ptáček, R., Bartůněk, $\mathbf{P}$. Lékař a pacient $v$ moderní medicíně: etické, právní, psychologické a klinické aspekty. Praha, Grada Publishing, 2015. Edice celoživotního vzdělávání ČLK. ISBN 978-80-247-5788-9.

9. Rada vlády pro záležitosti romské menšiny. Koncepce romské integrace ve Zlínském kraji na léta 2015-2018 [online]. Duben 2014 [cit. 2015-08-05]. Dostupné z WWW: https://www.krzlinsky.cz/docs/clanky/dokumenty/5399/koncepce-romske-integrace-ve-zlinskem-kraji-2015-2018.pdf

10. Tóthová, V., a kol. Prevence obezity a nadváhy u romské minority $v$ komunitním ošetřovatelství. Praha, Lidové noviny, 2016. ISBN 978-80-7422-4678-6.

11. Toušek, L. Kultura chudoby [online]. AntropoWebzin, 2015 [cit.
2016-05-24]. ISSN 1801-8807. Dostupné z: http://www.antropoweb.cz/cs/kultura-chudoby

12. Úřad vlády ČR. Strategie romské integrace do roku 2020 [online]. 6. leden 2015. [cit. 2015-10-12]. Dostupné z: http:// ec.europa.eu/justice/discrimination/files/roma_czech_republic_strategy2_cs.pdf.

Korespondující autorka Doc. PhDr. Alena Kajanová, Ph.D. Ústav sociálních a sociálně pedagogických věd

ZSF JU

Jírovcova 24

37004 České Budějovice e-mail: kajanova@zsf.jcu.cz
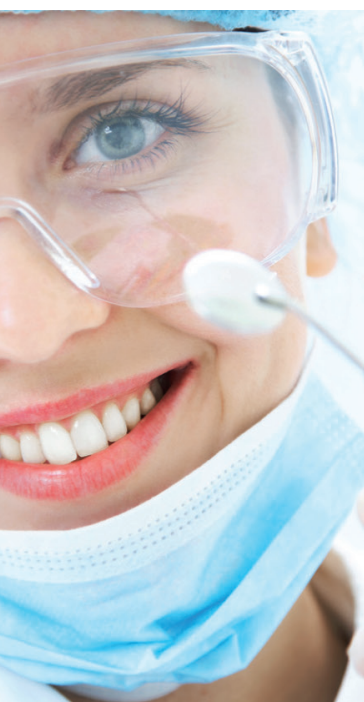

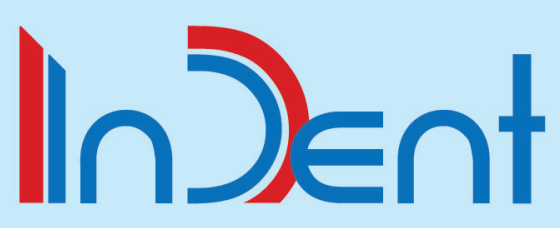

Mezinárodní dentální konference s výstavou

25.-27.5. 2017 Výstaviště Brno
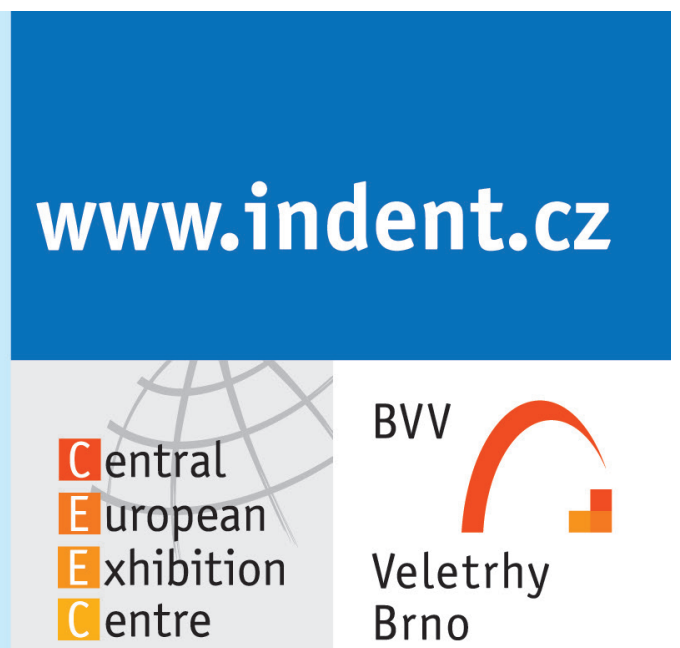

BVV

Veletrhy

Brno 